\title{
Effects of ozone on DNA single-strand breaks and 8-oxoguanine formation in A549 cells
}

\author{
Tsun-Jen Cheng, ${ }^{\text {a,* }}$ Hsuan-Peng Kao, ${ }^{\mathrm{a}}$ Chang-Chuan Chan, ${ }^{\mathrm{a}}$ and Wushou P. Chang ${ }^{\mathrm{b}}$ \\ ${ }^{a}$ Institute of Occupational Medicine and Industrial Hygiene, College of Public Health, National Taiwan University, \\ No. 1 Ren-Ai Rd., Sec. 1, Taipei 10018, Taiwan \\ ${ }^{\mathrm{b}}$ Institute of Environmental Health Sciences, National Yang-Ming University, Taipei, Taiwan
}

Received 16 September 2002; received in revised form 30 January 2003; accepted 26 February 2003

\begin{abstract}
Animal studies have demonstrated that ozone exposure can induce lung tumors. Recent epidemiological studies have also shown that increased ozone exposure is associated with a greater risk of lung cancer. This study used single-cell gel electrophoresis (the Comet assay) and flow cytometry to investigate DNA damage in A549 cells exposed to ozone levels below the current ambient standard. Cells were exposed to ozone at levels of 0,60, 80, and $120 \mathrm{ppb}$, and then DNA single-strand breaks and 8-oxoguanine levels were measured. Additionally, the formamidopyrimidine glycosylase (Fpg) repair enzyme was added to the Comet assay to enhance detection of oxidative damage. Vitamins $\mathrm{C}$ and $\mathrm{E}$ were also added to determine their inhibitory effects on ozone-induced 8oxoguanine. Measurements of tail length, tail intensity, and tail moment of the Comet assay were shown to correlate with each other. However, tail moment appeared to be more sensitive than the other two indicators in detecting DNA single-strand breaks. Tail moments of cells exposed to 80 and $120 \mathrm{ppb}$ of ozone were significantly higher than those exposed to $0 \mathrm{ppb}(P<0.05)$. These three indicators of DNA single-strand breaks with Fpg were shown to be increased and more sensitive than those without Fpg. After Fpg was introduced, the tail moments at ozone levels of 60,80 , and $120 \mathrm{ppb}$ were significantly higher than those at 0 ppb $(P<0.05)$. Furthermore, 8-oxoguanine levels, determined by fluorescence intensity, at 80 and $120 \mathrm{ppb}$ of ozone exposure were significantly higher than the level at $0 \mathrm{ppb}$. Pretreatment with vitamins $\mathrm{C}$ and E reduced the 8-oxoguanine levels caused by ozone. We conclude that ozone levels below current ambient standards may induce DNA breaks and oxidative DNA damage. Moreover, the Fpg repair enzyme in the Comet assay can increase the sensitivity of oxidative damage detection in vitro.
\end{abstract}

(C) 2003 Elsevier Science (USA). All rights reserved.

Keywords: Comet assay; Formamidopyrimidine glycosylase; 8-oxoguanine; Ozone; Vitamins C and E

\section{Introduction}

Increased ambient ozone levels are associated with pulmonary mortality and morbidity (Anderson et al., 1996; Burnett et al., 1997; Delfino et al., 1998; Hoek et al., 1997). Recent epidemiological studies have shown that increased ozone exposure is associated with a risk of lung cancer (Abbey et al., 1995; Lawrence et al., 1998). Animal studies have also demonstrated that ozone exposure can induce lung tumors (Hassett et al., 1985; Herbert et al., 1996; Last et al., 1987). However, the exact carcinogenic mechanisms of ozone remain less

Abbreviations: Fpg, formamidopyrimidine glycosylase; ROS, reactive oxygen species.

${ }^{*}$ Corresponding author. Fax: + 886-2-2395-7845.

E-mail address: tcheng@ha.mc.ntu.edu.tw (T.-J. Cheng). clear, particularly at levels around the current ambient standard.

Ozone is a strong oxidant that can generate reactive oxygen species (ROS) in tissue, resulting in DNA damage (Pryor, 1994). Single-cell gel electrophoresis, or the Comet assay, has been used to assess the effects of ozone on cell lines, as ROS has been shown to induce DNA single-strand breaks (Frenkel, 1992). Increased DNA single-strand breaks have also been associated with ozone exposure in epidemiological and animal studies (Haney et al., 1999; Rojas et al., 2000).

Those studies were conducted at ozone levels much greater than $100 \mathrm{ppb}$ for more than $1 \mathrm{~h}$. The current ozone standard set by the US Environmental Protection Agency is $125 \mathrm{ppb}$ in $1 \mathrm{~h}$. Herein, we determined DNA single-strand breaks in A549 cells exposed to ozone levels much lower than the current ambient standard for 
ozone in $1 \mathrm{~h}$. Further, we also performed a Comet assay with formamidopyrimidine glycosylase (Fpg), a specific enzyme used to repair oxidative DNA damage, to enhance the sensitivity for detecting oxidative damage (Andrea et al., 1996; Leipold et al., 2000; Lavrukhin and Lloyd, 2000).

Studies have shown that 8-oxoguanine is one of the most prevalent DNA adducts caused by ROS (Loft and Poulsen, 1996; Lawrence, 2000). Production of 8oxoguanine leads to $\mathrm{G}-\mathrm{A}$ transversion in vitro and in animal studies; $\mathrm{G}-\mathrm{A}$ transversion is a common mutation in the $p 53$ genes (Loft and Poulsen, 1996). In recent studies, 8-oxoguanine formation has been determined using flow cytometry (Futaki et al., 2002; Mei et al., 2002). Thus, in addition to DNA single-strand breaks, we used flow cytometry to further determine whether ozone levels below the current standard induce 8oxoguanine, a specific type of DNA damage that may initiate carcinogenesis. At the same time, antioxidants have been shown to decrease the oxidative damage in previous studies (Heike et al., 1993; Qi et al., 2000). In this study, the antioxidant effects of vitamins $\mathrm{C}$ and $\mathrm{E}$ were also tested in ozone-treated A549 cells.

\section{Methods and materials}

\subsection{A549 cell culture and exposure to ozone}

The human A549 cell line was from the American Type Culture Collection and was cultured in a humidified $37^{\circ} \mathrm{C}$ environment in F12-K medium supplemented with $10 \%$ fetal calf serum and $1 \%$ penicillin and streptomycin. This cell line, derived from a patient with alveolar cell carcinoma of the lung, has been used as a model of human alveolar type II cells. The in vitro ozone exposure system was modified from a previous design, which included a stainless-steel exposure chamber, an ozone generator, and a humidifier (Tarkington et al., 1994). These three compartments were connected by Teflon tubes. Ozone generated by an ozonizer (Thermo Environmental Instrument Inc., Model 146, Franklin, MA, USA), was mixed with $\mathrm{CO}_{2}$ and filtered air to provide predetermined ozone levels at $5 \% \mathrm{CO}_{2}$ for the experiments. The experimental air was first passed through a humidifier and then introduced from the top panel into the exposure chamber at approximately $3.5 \mathrm{~L} /$ min. A Teflon tube with multiple holes punched in it was used to distribute the humidified experimental air in order to ensure its even distribution inside the chamber. Ozone levels of $0,60,80$, and $120 \mathrm{ppb}$ at a constant humidity of $95 \pm 5 \%$ were maintained in the $0.14-\mathrm{m}^{3}$ exposure chamber throughout the experiment. An ozone analyzer (Thermo Environmental) was continuously used to monitor the ozone levels to ensure constant and even ozone concentrations inside the exposure chamber. The human A549 cells were exposed to 0, 60,80 , and $120 \mathrm{ppb}$ of ozone in the exposure chamber for $1 \mathrm{~h}$. Three sets of experiments were conducted for each level of ozone concentration. The viability of A549 cells was determined by trypan blue exclusion assay.

\subsection{Determination of DNA single-strand breaks by Comet assay}

The alkaline Comet assay was used to determine DNA single-strand breaks. Quantities of $20 \mu \mathrm{L}$ of A549 suspensions $\left(10^{5}\right.$ cells $\left./ \mathrm{mL}\right)$ were mixed with $1 \mathrm{~mL}$ of $1.5 \%$ low-melting agarose and gelled to frosted slides pretreated with $0.1 \%$ normal-melting agarose on ice. After gelling, the slides were immersed in alkaline lysis buffer $(2.5 \%$ SDS and $25 \mathrm{mM}$ EDTA, $\mathrm{pH}=13)$ for $10 \mathrm{~min}$, then washed with PBS. They were then placed in buffer $(30 \mathrm{mM} \mathrm{NaOH}$ and $1 \mathrm{mM}$ EDTA) for electrophoresis at $21 \mathrm{~V}$ and $190 \mathrm{~mA}$ for $20 \mathrm{~min}$. Subsequently, slides were rinsed and stained in sybr green. Individual cells were examined under a microscope with a photomicrographic system. All slides were coded and read blindly. The images were then recorded for further image analysis. We also used A549 cells that had been aliquoted previously as an internal standard to adjust for experimental variability (De Boeck et al., 2000).

In addition to the regular Comet assay, we also used Fpg, an endonuclease with specific activity toward oxidized purines, for the enhanced detection of oxidative damage. Briefly, slides and cells were prepared as described above and then immersed in lysis buffer for 10 min. After the slides were washed with enzyme reaction buffer, Fpg (Sigma) was added at a level of $10 \mu \mathrm{g} / \mathrm{mL}$ at $37^{\circ} \mathrm{C}$ for $30 \mathrm{~min}$. Following electrophoresis, the slides were stained and the images were recorded.

Proprietary image processing software, which has been used in previous studies (Ma et al., 1996; Gwo et al., 2003), was applied to calculate the distribution of DNA on the agarose. Images of 100 randomly selected cells from each set of the experiment were analyzed under a fluorescence microscope adapted with excitation at $515-560 \mathrm{~nm}$ and a barrier filter of $590 \mathrm{~nm}$. Parameters used in the analysis were tail length (\%), tail intensity (\%), and tail moment. Tail length $(\%)$ was defined as the proportion of tail length of the entire comet length; tail intensity (\%) was defined as the proportion of tail intensity of the total Comet intensity; and tail moment was defined as the product of tail length and tail intensity. We used the percentage of tail length because of its ease in measurement, as in the measurement of tail intensity (Ma et al., 1996).

\subsection{Determination of 8-oxoguanine levels by flow cytometry}

For the detection of oxidative DNA damage, 8oxoguanine, the OxyDNA assay kit was used (Biotrin, 
Dublin, Ireland). This reagent has affinity for the imidazilidone group, which is part of 8-oxoguanine. The manufacturer's protocols were followed. Briefly, $1 \times 10^{5}-5 \times 10^{5}$ cells were harvested and transferred to polystyrene flow cytometry tubes, washed with PBS, pelleted, and resuspended in $0.5 \mathrm{~mL}$ of PBS. After $0.5 \mathrm{~mL}$ of $2 \%$ paraformaldehyde was added, the solution was placed on ice for $15 \mathrm{~min}$. The cells were washed twice, resuspended in $1 \mathrm{~mL}$ of ice-cold ethanol, and stored at $-20^{\circ} \mathrm{C}$ until analysis. After washing, the nonspecific sites were blocked by incubation with blocking solution at $37^{\circ} \mathrm{C}$ for $1 \mathrm{~h}$. After washing, $100 \mu \mathrm{L}$ of FITC-conjugated protein specific for 8oxoguanine was incubated for $1 \mathrm{~h}$ in the dark at room temperature. After washing, the cells were rinsed, resuspended, and analyzed with a fluorescence-activated cell sorter (FACSCalibur system, Becton Dickinson). Fluorescence readings were done for $10^{4}$ cells for each set of experiments and analyzed with CELLQuest software. Mean fluorescence intensity was used to represent the 8-oxoguanine level. Cells were also treated with vitamins $\mathrm{C}$ and $\mathrm{E}$, respectively, at concentrations of $0,50,100$, and $200 \mu \mathrm{M}$ for $1 \mathrm{~h}$ before exposure to ozone. After $1 \mathrm{~h}$ of ozone exposure at $120 \mathrm{ppb}, 8$-oxoguanine levels were determined using flow cytometry.

\subsection{Statistical analysis}

Student's $t$ test was used to compare tail length (\%), tail intensity (\%), and tail moment between the controls and different ozone exposure groups. Similarly, mean fluorescence intensity for 8-oxoguanine levels was also compared between the controls and different ozone exposure groups. Last, the effect of vitamins $\mathrm{C}$ and $\mathrm{E}$ on mean fluorescence intensity was also compared between the controls and treated groups. A $P$ value of less than $5 \%$ was considered significant.

\section{Results}

After ozone treatment, cell viability decreased with the concentration of ozone (Fig. 1). Cell viabilities were $95 \%$ at $0 \mathrm{ppb}, 88 \%$ at $60 \mathrm{ppb}, 83 \%$ at $80 \mathrm{ppb}$, and $75 \%$ at $120 \mathrm{ppb}$ of ozone.

Tail length (\%), tail intensity (\%), and tail moment of DNA single-strand breaks increased with increased ozone levels (Table 1). Tail length increased from $58.1 \%$ to $65.1 \%$ when the ozone level increased from 0 to $120 \mathrm{ppb}$. Over the same range of ozone levels, tail intensity increased from $58.2 \%$ to $70.4 \%$, and the tail moment increased from 102.2 to 116.1 . At 80 and $120 \mathrm{ppb}$ of ozone, tail moments were significantly higher than that of the control $(P<0.05)$. However, the difference was not significant for either tail length or tail intensity. Subsequently, Fpg was added to the

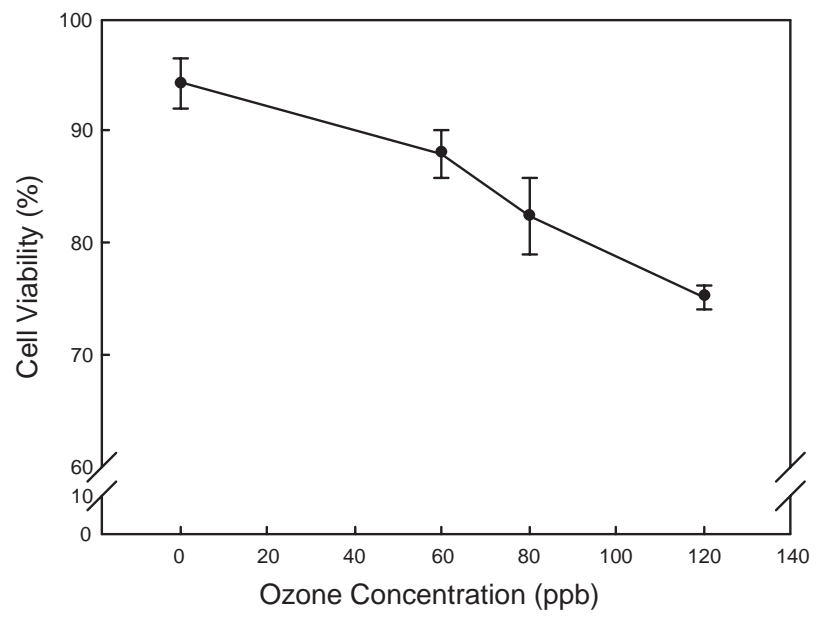

Fig. 1. Cell viability after exposure to ozone. Data are plotted as mean $\pm \mathrm{SE}(n=3)$.

Table 1

DNA single-strand breaks induced by ozone using Comet assay with and without Fpg enzymes

\begin{tabular}{llll}
\hline $\begin{array}{l}\text { Concentrations } \\
\text { of ozone }(\mathrm{ppb})\end{array}$ & $\begin{array}{l}\% \text { tail length } \\
( \pm \mathrm{SE})\end{array}$ & $\begin{array}{l}\text { \% tail intensity } \\
( \pm \mathrm{SE})\end{array}$ & $\begin{array}{l}\text { Tail moment } \\
( \pm \mathrm{SE})\end{array}$ \\
\hline Without Fpg & & & \\
$\quad 0$ & $58.1 \pm 4.9^{\mathrm{a}}$ & $58.2 \pm 7.8$ & $102.2 \pm 1.3$ \\
60 & $58.5 \pm 5.2$ & $63.9 \pm 7.6$ & $104.0 \pm 5.3$ \\
80 & $63.0 \pm 5.5$ & $68.4 \pm 7.6$ & $114.3 \pm 1.0^{*}$ \\
120 & $65.1 \pm 5.2$ & $70.4 \pm 6.6$ & $116.1 \pm 2.8^{*}$ \\
& & & \\
With Fpg & & & $110.9 \pm 3.0$ \\
0 & $74.5 \pm 5.5$ & $78.4 \pm 5.0$ & $162.0 \pm 1.5^{*}$ \\
60 & $76.2 \pm 4.8$ & $86.2 \pm 4.6$ & $190.1 \pm 1.5^{*}$ \\
80 & $83.2 \pm 4.6$ & $93.0 \pm 3.5^{*}$ & $199.1 \pm 1.1^{*}$ \\
120 & $85.9 \pm 4.7^{*}$ & $93.5 \pm 3.2^{*}$ & \\
\hline
\end{tabular}

${ }^{*} P<0.05$ compared to the experiment at $0 \mathrm{ppb}$.

${ }^{\mathrm{a}}$ Mean $\pm \operatorname{SE}(n=3), 100$ cells were scored for each experiment.

Comet assay. Tail length, tail intensity, and tail moment with Fpg treatment were greater than those without Fpg. Tail lengths increased with ozone levels from $74.5 \%$ to $85.9 \%$, and measurements at $120 \mathrm{ppb}$ were significantly greater than those at $0 \mathrm{ppb}$. Tail intensity also increased with ozone levels from $78.4 \%$ to $93.5 \%$. Tail intensities at 80 and $120 \mathrm{ppb}$ were significantly greater than those at $0 \mathrm{ppb}$. Furthermore, tail moment increased from 110.9 to 199.1 . Tail moments at ozone levels of 60,80 , and $120 \mathrm{ppb}$ were greater than those at 0 ppb $(P<0.05)$.

Similarly, 8-oxoguanine levels determined by mean fluorescence levels increased with ozone levels (Fig. 2). At $0 \mathrm{ppb}$ of ozone, 8 -oxoguanine was 10.7 ; at $60 \mathrm{ppb}$, it was 67.6 ; at $80 \mathrm{ppb}$, it was $328.3(P<0.05)$; and at $120 \mathrm{ppb}$, it was $290.1(P<0.05)$.

When cells were treated with vitamin $\mathrm{C}$ at the levels of $0,50,100$, and $200 \mu \mathrm{M}$ before ozone exposure, mean fluorescence intensity of 8-oxoguanine significantly 


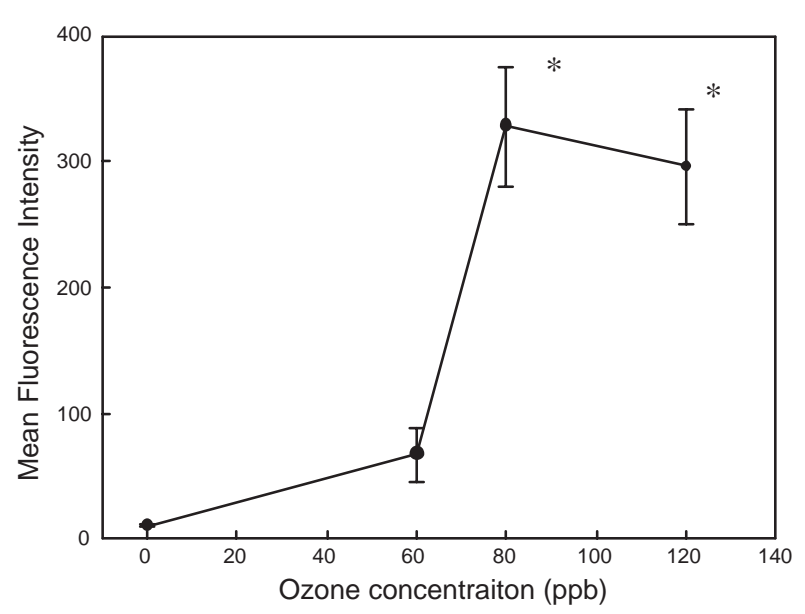

Fig. 2. 8-oxoguanine levels detected by fluorescence in A549 cells after ozone exposure. Data are plotted as mean \pm SE $(n=3), 10,000$ cells were scored for each experiment. ${ }^{*} P<0.05$, compared to the experiment at $0 \mathrm{ppb}$.

decreased from 261.3 to $46.1,44.7$, and 25.4 (inhibited by $72-86 \%$ ) (Fig. 3). Similar results were also found with vitamin $\mathrm{E}$ treatment. The mean fluorescence intensity of 8-oxoguanine significantly decreased from 204.8 to $56.5,35.4$, and 28.0 after vitamin E treatment (inhibited by $82-90 \%$ ) (Fig. 3).

\section{Discussion}

The results showed that ozone exposure at $80 \mathrm{ppb}$ could induce increased oxidative DNA damage, including 8-oxoguanine and DNA single-strand breaks. Adding Fpg further increased the sensitivity in detecting oxidative damage caused by ozone.

The Comet assay has been used to determine oxidative DNA damage. In a previous epidemiological study, subjects with higher exposure to ozone had higher levels of DNA single-strand breaks (Rojas et al., 2000). The average ozone levels in the high-exposure area ranged from 160 to $170 \mathrm{ppb}$. In rats exposed to 250 and $500 \mathrm{ppb}$ for $3 \mathrm{~h}$, cells from bronchoalveolar lavage had higher levels of DNA single-strand breaks (Haney et al., 1999). Similar findings were observed in in vitro studies. Human bronchial cell lines also had higher levels of DNA single-strand breaks after exposure to 100 and $200 \mathrm{ppb}$ of ozone for $2 \mathrm{~h}$ (Lee et al., 1996). When normal human tracheobronchioepithelial cells were exposed to $400 \mathrm{ppb}$ of ozone for $40 \mathrm{~min}$, DNA single-strand breaks were significantly increased (Lee et al., 1996). Thus, increased oxidative damage may be detected when exposed to an ozone level of $100 \mathrm{ppm}$ for more than $1 \mathrm{~h}$. In this study, we used a regular Comet assay and observed a significant increase in DNA single-strand breaks with an ozone level of $80 \mathrm{ppb}$ for $1 \mathrm{~h}$. The mechanisms through which ozone induces DNA single-
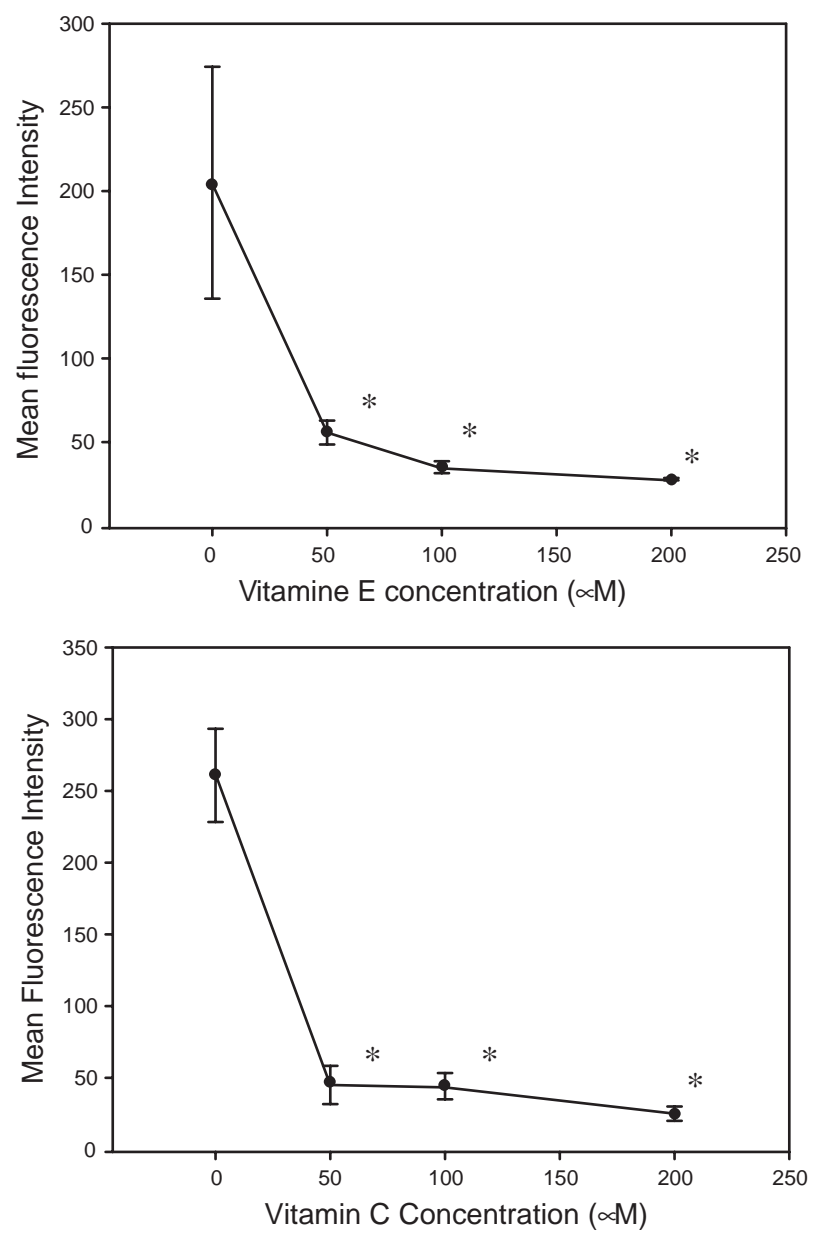

Fig. 3. Inhibitory effects of vitamins $\mathrm{C}$ and $\mathrm{E}$ on ozone-induced 8oxoguanine levels detected by fluorescence in A549 cells. Data are plotted as mean $\pm \mathrm{SE}(n=3), 10,000$ cells were scored for each experiment. ${ }^{*} P<0.05$, compared to the experiment at $0 \mathrm{ppb}$.

strand breaks are less clear. A recent study suggested that DNA single-strand breaks induced by ozone may be mediated through $\mathrm{H}_{2} \mathrm{O}_{2}$ production (Diaz-Llera et al., 2002). In the same study, formation of DNA singlestrand breaks was inhibited by pretreatment using catalase.

Using Fpg to enhance the sensitivity of the Comet assay we were able to detect increased oxidative damage at an ozone level of $60 \mathrm{ppb}$. The Fpg enzyme can remove 8 -oxoguanine and other oxidative damage. Studies have revealed that $30-50 \%$ of oxidative damage removed by Fpg is due to 8-oxoguanine (Boiteux et al., 1992; Karakaya et al., 1997). The Comet assay with Fpg has been demonstrated to be more sensitive in previous studies (Andrea et al., 1996; Hodges et al., 2001). Our study also showed similar findings. It appears that the Comet assay with Fpg enzymes is a useful methodology for detecting oxidative DNA damage.

Although the Comet assay has been used to assess oxidative DNA damage caused by ozone, it is not clear whether ozone can cause specific DNA damage. Studies 
have shown that 8-oxoguanine is a sensitive marker of oxidative DNA damage and is implicated in carcinogenesis (Park and Floyd, 1992; Loft and Poulsen, 1996). However, 8-oxoguanine has not been used in previous studies to detect the effects of ozone. In this study, we used flow cytometry to determine 8-oxoguanine levels in A549 cells caused by ozone. Interestingly, increased 8oxoguanine levels were observed in A549 cells exposed to ozone levels as low as $80 \mathrm{ppb}$. Our results support previous epidemiological and animal studies that ozone may play a role in carcinogenesis. A previous study also showed a decrease in 8-oxoguanine levels in chromiumand $\mathrm{H}_{2} \mathrm{O}_{2}$-treated cells after administering vitamins $\mathrm{C}$ and E (Qi et al., 2000). Our study also produced similar finding. This suggests that ozone-induced ROS may be scavenged by antioxidants.

Our results indicate that ozone exposure at $60-80 \mathrm{ppb}$ for $1 \mathrm{~h}$ can induce DNA single-strand breaks and specific 8-oxoguanine formation in A549 cells. We conclude that possible carcinogenesis due to chronic ozone exposure warrants further study.

\section{Acknowledgments}

This study was supported by grants from the National Science Council, Taiwan (NSC-89-2621-Z-002-029 and NSC-90-2621-Z-002-031).

\section{References}

Abbey, D.E., Lebowitz, M.D., Mills, P.K., 1995. Long-term ambient concentrations of particulates and oxidants and development of chronic disease in a cohort of nonsmoking California residents. Inhalation Toxicol. 7, 19-34.

Anderson, H.R., Ponce de, L.A., Bland, J.M., Bower, J.S., Strachan, D.P., 1996. Air pollution and daily mortality in London: 19871992. Br. Med. J. 312, 665-669.

Andrea, H., Heike, D., Regina, S., 1996. Sensitive analysis of oxidative DNA damage in mammalian cells: use of the bacterial Fpg protein in combination with alkaline unwinding. Toxicol. Lett. 88, 85-90.

Boiteux, S., Ewa, G., Jacques, L., Miral, D., 1992. Substrate specificity of the Escherichia coli Fpg protein (formamidopyrimidineDNA glycosylase): excision of purine lesions in DNA produced by ionizing radiation or photosensitization. Biochemistry 31 , 106-110.

Burnett, R.T., Brook, J.R., Yung, W.T., Dales, R.E., Krewski, D., 1997. Association between ozone and hospitalization for respiratory diseases in 16 Canadian cities. Environ. Res. 72, 24-31.

De Boeck, M., Touil, N., De Visscher, G., Vande, P.A., Kirsch-Volders, M., 2000. Validation and implementation of an internal standard in Comet assay analysis. Mutat. Res. 469, 181-197.

Delfino, R.J., Murphy-Moulton, A.M., Becklake, M.R., 1998. Emergency room visits for respiratory illnesses among the elderly in Montreal: association with low-level ozone exposure. Environ. Res. 76, 67-77.
Diaz-Llera, S., Gonzalez-Hernandez, Y., Prieto-Gonzalez, E.A., Azoy, A., 2002. Genotoxic effect of ozone in human peripheral blood lymphocytes. Mutat. Res. 517, 13-20.

Frenkel, K., 1992. Carcinogen-mediated oxidant formation and oxidative DNA damage. Pharmacol. Ther. 53, 127-166.

Futaki, M., Igarashi, T., Watanabe, S., Kajigaya, S., Tatsuguchi, A., Wang, J., Liu, J.M., 2002. The FANCG Fanconi anemia protein interacts with CYP2E1: possible role in protection against oxidative DNA damage. Carcinogenesis 23, 67-72.

Gwo, J.G., Wu, T.Y., Chang, W.P., 2003. Comet assay evaluation of DNA damage in fresh and cryopreserved pacific oyster (Crassostrea gigas) spermatozoa. In press.

Haney Jr., J.T., Connor, T.H., Li, L., 1999. Detection of ozoneinduced DNA single strand breaks in murine bronchoalveolar lavage cells acutely exposed in vivo. Inhalation Toxicol. 11, 331-341.

Hassett, C., Mustafa, M.G., Coulson, W.F., Elashoff, R.M., 1985. Murine lung carcinogenesis following exposure to ambient ozone concentrations. J. Natl. Cancer Inst. 75, 771-777.

Heike, B., Anne, K.M., Irene, K., Klaus, E.A., 1993. $\mathrm{NO}_{2}$-induced DNA single strand breaks are inhibited by antioxidative vitamins in V79 cells. Chem. Biol. Interact. 86, 199-211.

Herbert, R.A., Hailey, J.R., Grumbein, S., Chou, B.J., Sills, R.C., Haseman, J.K., Goehl, T., Miller, R.A., Roycroft, J.H., Boorman, G.A., 1996. Two-year and lifetime toxicity and carcinogenicity studies of ozone in $\mathrm{B} 6 \mathrm{C} 3 \mathrm{~F} 1$ mice. Toxicol. Pathol. 24, 539-548.

Hodges, N.J., Adam, B., Lee, A.J., Cross, H.J., Chipman, J.K., 2001. Induction of DNA-strand breaks in human peripheral blood lymphocytes and A549 lung cells by sodium dichromate: association with 8-oxo-2-deoxyguanosine formation and inter-individual variability. Mutagenesis 16, 467-474.

Hoek, G., Schwartz, J.D., Groot, B., Eilers, P., 1997. Effects of ambient particulate matter and ozone on daily mortality in Rotterdam, the Netherlands. Arch. Environ. Health 52, 455-463.

Karakaya, A., Pawel, J., Vilhelm, A.B., Arthur, P.G., Miral, D., 1997. Kinetics of excision of purine lesions from DNA by Escherichia coli Fpg protein. Nucleic Acids Res. 25, 474-479.

Last, J.A., Warren, D.L., Pecquet-Goad, E., Witschi, H., 1987. Modification by ozone of lung tumor development in mice. J. Natl. Cancer Inst. 78, 149-154.

Lavrukhin, O.V., Lloyd, R.S., 2000. Involvement of phylogenetically conserved acidic amino acid residues in catalysis by an oxidative DNA damage enzyme formamidopyrimidine glycosylase. Biochemistry $39,15266-15271$.

Lawrence, J.M., 2000. Oxyradicals and DNA damage. Carcinogenesis $21,361-370$.

Lawrence, W.B., Abbey, D.E., Knutsen, S.F., 1998. Long-term concentrations of ambient air pollutants and incident lung cancer in California adults: results from the AHSMOG study. Environ. Health Perspect. 106, 813-822.

Lee, J.G., Madden, M.C., Reed, W., Adler, K., Devlin, R., 1996. The use of the single cell gel electrophoresis assay in detecting DNA single strand breaks in lung cells in vitro. Toxicol. Appl. Pharmacol. 141, 195-204.

Leipold, M.D., Muller, J.G., Burrows, C.J., David, S.S., 2000. Removal of hydantoin products of 8-oxoguanine oxidation by the Escherichia coli DNA repair enzyme, FPG. Biochemistry 39, 14984-14992.

Loft, S., Poulsen, H.E., 1996. Cancer risk and oxidative DNA damage in man. J. Mol. Med. 74, 297-312.

Ma, S., Chang, W.P., Fang, R.-H., 1996. Measure of radiationinduced DNA double-strand breaks in human diploid fibroblasts from keloid and normal skin by single-cell gel electrophoresis. Plast. Reconstr. Surg. 98, 821-826. 
Mei, N., Kunugita, N., Hirano, T., Kasai, H., 2002. Acute arseniteinduced 8-hydroxyguanine is associated with inhibition of repair activity in cultured human cells. Biochem. Biophys. Res. Commun. 297, 924-930.

Park, J.W., Floyd, R.A., 1992. Lipid peroxidation products mediate the formation of 8-hydroxydeoxyguanosine in DNA. Free Radical Biol. Med. 12, 245-250.

Pryor, W.A., 1994. Mechanisms of radical formation from reactions of ozone with target molecules in the lung. Free Radical Biol. Med. 17, 451-465.

Qi, W., Russel, J.R., Dun-Xian, T., Joaquin, J.G., Lucien, C.M., Malgorzata, K., Juan, R.C., 2000. Chromiium(III)-induced 8- hydroxydeoxyguanosine in DNA and its reduction by antioxidants: comparative effects of melatonin, ascorbate, and vitamin E. Environ. Health Perspect. 108, 399-402.

Rojas, E., Valverde, M., Lopez, M.C., Naufal, I., Sanchez, I., Bizarro, P., Lopez, I., Fortoul, T.I., Ostrosky-Wegman, P., 2000. Evaluation of DNA damage in exfoliated tear duct epithelial cells from individuals exposed to air pollution assessed by single cell gel electrophoresis assay. Mutat. Res. 468, 11-17.

Tarkington, B.K., Wu, R., Sun, W.M., Nikkula, K.J., Wilson, D.W., Last, J.A., 1994. In vitro exposure of tracheobronchial epithelial cells and of tracheal explants to ozone. Toxicology 88 , $51-68$. 